ks. dr Józef Młyński

UNIWERSYTET KARDYNAŁA STEFANA WYSZYŃSKIEGO W WARSZAWIE

\title{
Rodzina między pracą a migracją zarobkową w analizie społeczno-socjologicznej
}

\section{Wstęp}

Rodzina jest jedynym społecznie uznanym środowiskiem zrodzenia i wychowania potomstwa. W tym aspekcie pozostaje również najważniejszą agendą socjalizującą. Zaś opierając się na więzach krwi: małżeńskich i rodzicielskich, relacjach pozostaje naturalnym środowiskiem opiekuńczym oraz środowiskiem kształtowania ludzkiej godności i aksjologii życia. Dlatego też dobro potomstwa domaga się trwałości małżeństwa i rodziny. Niestety powszechnie wiadomo, że w przypadku trudności pojawiających się w rodzinie, a nawet jej rozpadu, dzieci zostają pierwszymi ofiarami dramatu małżeńsko-rodzinnych losów1. Oczywiście istnieje wiele przyczyn destrukcji rodziny, ale wśród nich coraz częściej genezą rozdarcia i kryzysu $\mathrm{w}$ rodzinie jest migracja zarobkowa.

Przez termin "migracja” należy rozumieć szeroko posunięty proces przemieszczania się ludności w określonych celach. Pochodzi

1 W. Majkowski, Rodzina polska w kontekście nowych uwarunkowań, Kraków 2012, s.75. 
od łacińskiego słowa migratio, co oznacza przeniesienie się z jednego miejsca $\mathrm{w}$ inne $\mathrm{e}^{2}$. Według encyklopedycznego rozumienia to jedna z form przestrzennej mobilności oznaczająca terytorialne przemieszczenia jednostek w danym obszarze ${ }^{3}$. Z kolei w ujęciu słownika języka polskiego to „wędrówka, ruch ludności mający na celu zmianę miejsca pobytu na stałe lub okresowo, zarówno w obrębie kraju, jak i z jednego kraju do drugiego"4.

Niewątpliwie rodzina migracyjna to rodzina, w której jedno ze współmałżonków (lub oboje) wyjechało do innego kraju w celu poszukiwania pracy bądź podniesienia statusu ekonomicznego. Rodzina, w której jedno bądź oboje rodziców emigruja, staje się rodziną czasowo niepełną. Oznacza to, że w danym okresie zmaga się ona z problemami właściwymi rodzinom czasowo niepełnym.

Wydaje się, że emigracja rodziców jest najtrudniejsza dla dzieci. Wprawdzie pozostają one pod opieką dziadków, ale mimo to doświadczają szczególnej rozłąki i odarcia rodzicielskiego. W sytuacji migracji całej rodziny zjawisko to jest najmniej destrukcyjne. W tej bowiem mobilności społecznej „rodzina nie doświadcza negatywnych skutków rozstania: samotności, osłabienia małżeńsko-rodzinnych więzi, a małżonkowie nie są bezpośrednio wystawieni na pokusy kuszących alternatyw w nowym środowisku"s. Ponadto dzieci nie doświadczają poczucia braku rodziców, rozłąki oraz dezorganizacji życia rodzinnego.

2 A. Rajkiewicz, Polityka społeczna wobec procesów migracyjnych, [w:] Polityka spoleczna, red. G. Firlit-Fesnak, M. Szylko-Skoczny, Warszawa 2008, s. 303.

3 Migracja, [w:] Encyklopedia PWN, Warszawa 1979, s. 653.

4 Stownik języka polskiego PWN, red. M. Szymczak, Warszawa 1979.

5 W. Majkowski, Konsekwencje emigracji dla wspótczesnej rodziny polskiej, [w:] Rodzina a migracja, red. J. Młyński, W. Szewczyk, Kraków 2012, s. 111. 
Do rodzin migracyjnych zalicza się również rodzinę, z której dorosłe dziecko wyjeżdża w poszukiwaniu pracy. Jak zaznacza Władysław Majkowski, to stosunkowo mało bolesna forma emigracji. Jednakże „nie oznacza to, że jest to coś zwykłego i naturalnego. Wprawdzie jest rzeczą naturalną, że człowiek opuści ojca i matkę, ale dzieje się to celem połączenia z żoną, zwykle w ramach wspólnoty etnicznej”.

Jan Paweł II, odwołując się do problemu migracji, uważa, że emigracja za pracą jest zjawiskiem ciągle powracającym $\mathrm{w}$ analizach społeczno-ekonomiczno-kulturowych. Chociaż zjawisko to cechują różnorodność racjonalizacji i eksploracja w przestrzeni świata i choć może ono komplikować ludzkie życie, to jednak człowiek ma prawo do opuszczenia swojego kraju pochodzenia z różnych powodów, aby szukać lepszych warunków bytowania (LE 23). Dlatego też warto zastanowić się nad tezą dotyczącą wartości pracy i migracji zarobkowej w rodzinie. $\mathrm{W}$ tym kontekście należy nie tylko dokonać analizy diagnozy migracji, ale również zwrócić uwagę na dylematy w rodzinie związane z tym zjawiskiem, jej blaski oraz konsekwencje dla rodziny.

\section{Wartość pracy a rynel pracy w rodzinie}

Praca to wartość należąca do kategorii ludzkiego życia. Z jednej strony określa indywidualny kształt człowieczego bytowania, z drugiej jest fundamentalnym wymiarem każdego społeczeństwa. Dlatego też lokuje się w centrum tzw. kwestii społecznej. Odgrywa podstawową rolę w określeniu materialno-cywilizacyjnych warunków

6 W. Majkowski, Konsekwencje emigracji dla wspótczesnej rodziny polskiej, dz. cyt., s. 113. 
Józef Młyński

ludzkiego życia i decyduje w dużej mierze o charakterze stosunków społecznych. Praca zatem to ogół czynności polegających na przekształcaniu zasobów i cech przyrody w celu wytwarzania dóbr i usług zaspokajających ludzkie potrzeby?

Praca pozostaje zatem ontologiczną manifestacją człowieka. W jej dziełach wyrażamy tajemnicę naszego istnienia. Pracując, walczymy ze złem, z chaosu wydobywamy formy, tworzymy cywilizację, która zabezpiecza nas przed kaprysami przyrody - ślepej, choć także poddanej prawom. Naszym dążeniem jest przekształcenie sytuacji krytycznych w sytuacje organiczne, w sytuacje naprawdę ludzkie, gdzie człowiek bez trudu mógłby odnaleźć samego siebie ${ }^{8}$. Stąd „płynie waga etycznej refleksji nad praca, pozwalającej na ocenę rozmaitych jej form i społecznych wymiarów".

Jan Paweł II, podejmując temat pracy ludzkiej w encyklice Laborem exercens, uważa, iż jest ona powołaniem człowieka, które służy do jego rozwoju oraz kształtowania postaw społecznych. Wynika stąd zatem, że „praca jest poniekąd warunkiem zakładania rodziny, rodzina bowiem domaga się środków utrzymania, które w drodze zwyczajnej nabywa człowiek przez pracę. Praca i pracowitość warunkują także cały proces wychowania w rodzinie właśnie z tej racji, że każdy „staje się człowiekiem” między innymi przez pracę, a owo stawanie się człowiekiem oznacza właśnie istotny cel całego procesu wychowania. Oczywiście, że wchodzą tutaj w grę poniekąd dwa znaczenia pracy: ta, która warunkuje życie i utrzymanie rodziny - i ta

7 Multimedialna encyklopedia PWN, Warszawa 2000.

8 P. Trzebuchowski, Praca jako znak człowieczeństwa, Warszawa 1982, s. 102.

9 K. Krajeński, Etyka pracy, [w:] Człowiek-praca-globalizacja, red. W. Dłubacz, Nowy Sącz 2003, S. 15. 
poprzez którą urzeczywistniają się cele rodziny, zwłaszcza wychowanie; niemniej jednak te dwa znaczenia pracy łączą się z sobą i dopełniają w różnych punktach" (LE 10). Konstytuuje ona nie tylko wspólnotowy charakter rodziny, jej ekonomiczną kondycję, ale pozostaje w pewnym sensie szkołą rozwoju jednostki w społeczeństwie.

Nie ulega wątpliwości, że praca dla każdego człowieka jest nie tylko bardzo ważnym elementem życia, ale też konstytutywnym wymiarem jego funkcjonowania w przestrzeni społecznej. Zaspokaja bowiem potrzeby osobiste człowieka oraz jest podstawą rodzinnego budżetu. Niestety sytuacja na rynku pracy na przestrzeni ostatnich lat jest bardzo trudna. I chociaż mobilność zawodowa Polaków w tym zakresie jest szeroko rozwinięta, to jednak pomimo ciągłego podwyższania przez nich kwalifikacji (kursy, szkolenia) trudno jest znaleźć pracę. Właściwie współczesny człowiek jest na rynku pracy niejako zdany na los, bowiem nie tylko nie znajduje pracy zgodnej z jego wykształceniem, ale permanentnie pozostaje w obszarach poszukiwania jej, nawet podejmując zawody o niższym prestiżu społecznym.

Zjawisko bezrobocia urasta do problemów społecznych, a jego efekt jest powiązany z ciągłym zamykaniem dużej liczy zakładów. Problem upadłości zakładów dotyczy globalnej polityki ekonomicznej w państwie. W Polsce w roku 2008 zanotowano 425 upadłości ${ }^{10}$. Liczbowo problem ten w poszczególnych województwach w latach 2007 i 2008 przedstawiono na wykresie 1.

Niewątpliwie bardzo niepokojącym elementem rynku pracy jest bezrobocie. Bezrobocie - jak się wydaje - jest również nie tylko jednym z motywów migracji zarobkowej Polaków, ale też pierwszą

10 Raport: Płynność finansowa firm w Polsce, http://inwestycje.pl/firma/Raport-Plynnosc-finansowa-firm-w-Polsce;48885;0.html (29.12.2011). 
przyczyną szeroko rozpowszechnionej biedy w Polsce. Problem ten w ostatnich latach wciąż narasta ${ }^{11}$. Zjawisko eskalacji bezrobocia prezentuje tabela 1 .

Wykres 1: Upadłości zakładów w Polsce w roku 2007 i 2008

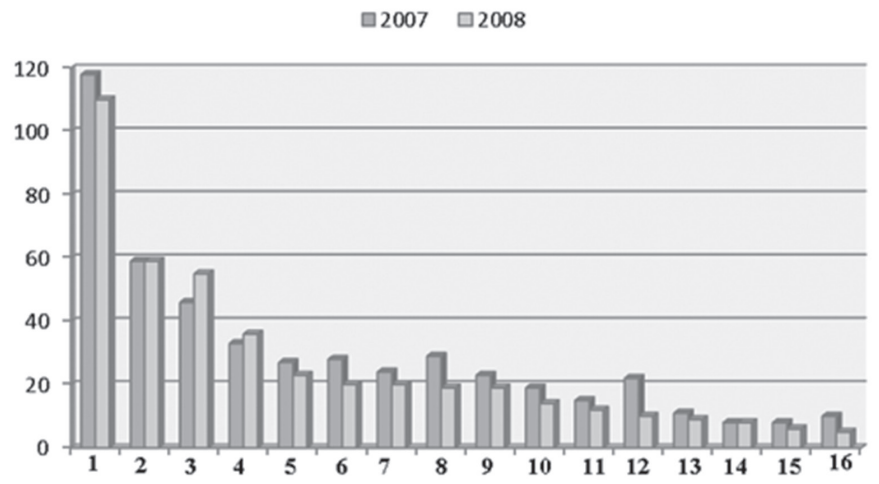

1 - mazowieckie (118,110); 2 - śląskie (59,59); 3 - dolnośląskie (46,55); 4 - zachodniopomorskie (33,36); 5 -lubelskie (27,23); 6- małopolskie (28,20); 7-warmińsko-mazurskie (24,20); 8-kujawsko-pomorskie (29,19); 9 - wielkopolskie (23,19); 10- pomorskie (19,14); 11 - łódzkie (15,12); 12 - podkarpackie (22,10); 13 - lubuskie (11,9); 14 - świętokrzyskie $(8,8) ; \mathbf{1 5}$ - opolskie $(8,6) ; \mathbf{1 6}$ - podlaskie $(10,5)$.

Istotnie ważnym czynnikiem rynku pracy w Polsce są relatywnie niskie płace oraz zatrudnianie na tak zwanych umowach śmieciowych. Z jednej strony względnie niska płaca w kraju ojczystym sprawia, że zdecydowania część ludzi poszukujących pracy poszukuje jej poza krajem własnego zamieszkania, tym bardziej że praca oferowana w Polsce - często fizyczna, $\mathrm{z}$ brakiem perspektyw rozwoju zawodowego, bez zapewnienia stabilności, z niskim wynagrodzeniem - nie jest

11 Zob. B. Mierzwiński, Bezrobocie jako problem rodzinny, [w:] Rodzina polska u progu trzeciego tysiąclecia, red. W. Majkowski, Warszawa 2003, s. 51. 
dla większości osób atrakcyjna, zwłaszcza jeśli bez problemu moga podjąć (przynajmniej kilkakrotnie lepiej płatną) pracę poza granicami kraju, nie tylko w wyuczonym zawodzie, ale w ogóle jakąkolwiek, i to bez względu na wiek. $Z$ kolei zatrudnianie przez pracodawców jedynie na umowach śmieciowych nie tylko nie daje stabilności posiadania pracy, ale też nie pozwala jednostkom zaplanować przyszłości.

Tabela 1: Zjawisko eskalacji bezrobocia w Polsce w ostatnim dwudziestoleciu

\begin{tabular}{|c|c|c|c|c|c|c|c|c|c|c|c|c|}
\hline & I & II & III & IV & $\mathbf{V}$ & VI & VII & VIII & IX & $\mathbf{X}$ & XI & XII \\
\hline 2013 & 14,0 & 14,4 & 14,3 & 14,0 & 13,6 & 13,2 & 13,1 & 13,0 & 13,0 & 13,0 & 13,2 & 13,9 \\
\hline 2012 & 13,2 & 13,5 & 13,4 & 13,1 & 12,6 & 12,3 & 12,3 & 12,4 & 12,4 & 12,5 & 12,9 & 13,4 \\
\hline 2010 & 12,9 & 13,2 & 13 & 12,4 & 12,1 & 11,7 & 11,5 & 11,4 & 11,5 & 11,5 & 11,7 & 12,4 \\
\hline 2009 & 10,4 & 10,9 & 11,1 & 10,9 & 10,7 & 10,6 & 10,7 & 10,8 & 10,9 & 11,1 & 11,4 & 12,1 \\
\hline 2008 & 11,5 & 11,3 & 10,9 & 10,3 & 9,8 & 9,4 & 9,2 & 9,1 & 8,9 & 8,8 & 9,1 & 9,5 \\
\hline 2007 & 15,1 & 14,8 & 14,3 & 13,6 & 12,9 & 12,3 & 12,1 & 11,9 & 11,6 & 11,3 & 11,2 & 11,2 \\
\hline 2005 & 19,4 & 19,4 & 19,2 & 18,7 & 18,2 & 18,0 & 17,9 & 17,7 & 17,6 & 17,3 & 17,3 & 17,6 \\
\hline 2004 & 20,6 & 20,6 & 20,4 & 19,9 & 19,5 & 19,4 & 19,3 & 19,1 & 18,9 & 18,7 & 18,7 & 19,0 \\
\hline 2003 & 20,6 & 20,7 & 20,6 & 20,3 & 19,8 & 19,7 & 19,6 & 19,5 & 19,4 & 19,3 & 19,5 & 20,0 \\
\hline \multirow{2}{*}{2002} & a. 18,1 & 18,2 & 18,2 & 17,9 & 17,3 & 17,4 & 17,5 & 17,5 & 17,6 & 17,5 & 17,8 & 18,0 \\
\hline & b. 20,1 & 20,2 & 20,1 & 19,9 & 19,2 & 19,4 & 19,4 & 19,5 & 19,5 & 19,5 & 19,7 & 20,0 \\
\hline 2001 & 15,7 & 15,9 & 16,1 & 16,0 & 15,9 & 15,9 & 16,0 & 16,2 & 16,3 & 16,4 & 16,8 & 17,5 \\
\hline 2000 & 13,7 & 14,0 & 14,0 & 13,8 & 13,6 & 13,6 & 13,8 & 13,9 & 14,0 & 14,1 & 14,5 & 15,1 \\
\hline 1997 & 13,1 & 13,0 & 12,6 & 12,1 & 11,7 & 11,6 & 11,3 & 11,0 & 10,6 & 10,3 & 10,3 & 10,3 \\
\hline 1996 & 15,4 & 15,5 & 15,4 & 15,1 & 14,7 & 14,3 & 14,1 & 13,8 & 13,5 & 13,2 & 13,3 & 13,2 \\
\hline 1995 & 16,1 & 15,9 & 15,5 & 15,2 & 14,8 & 15,2 & 15,3 & 15,2 & 15 & 14,7 & 14,7 & 14,9 \\
\hline 1994 & 16,7 & 16,8 & 16,7 & 16,4 & 16,2 & 16,6 & 16,9 & 16,8 & 16,5 & 16,2 & 16,1 & 16,0 \\
\hline 1991 & 6,6 & 6,8 & 7,1 & 7,3 & 7,7 & 8,4 & 9,4 & 9,8 & 10,5 & 10,8 & 11,1 & 12,2 \\
\hline 1990 & 0,3 & 0,8 & 1,5 & 1,9 & 2,4 & 3,1 & 3,8 & 4,5 & 5,0 & 5,5 & 5,9 & 6,5 \\
\hline
\end{tabular}

Źródło: Dane GUS Warszawa, „Rocznik Statystyczny” 1992, 1995, 2005, 2010; GUS, Aktywność ekonomiczna ludności Polski w latach 1992-2004, Warszawa 2005; GUS, „Mały Rocznik Statystyczny" 2010, 2011,2012, 2013. 
Powyżej zostały wymienione tylko niektóre czynniki ukazujące trudny rynek pracy w Polsce. Deskrypcja tych czynników pozwala uświadomić sobie, jak trudno żyje się pewnej części społeczeństwa. Bez względu na płeć i wiek dynamika rozwoju rynku pracy wpływa demotywująco na proces życia tych, którzy nie potrafią odnaleźć się w przestrzeni społecznej. Dlatego też pewna część społeczeństwa, szczególnie młodzi, opuszcza Polskę, by poszukać pracy i realizacji swojego życia poza granicami.

\section{Migracja zarobkowa - skala zjawiska i diagnoza społeczna}

Trudno jest ocenić skalę migracji zarobkowej Polaków. Z dostępnej literatury i informacji podawanych w mediach wynika, że po 2004 roku z Polski w celach zarobkowych wyjechały 2 miliony ludzi. Faktyczna jednak liczba migrujących jest o wiele większa i rośnie szczególnie w okresach wiosenno-wakacyjnych. W tym bowiem czasie Polacy wyjeżdżają do sezonowej pracy. Współcześnie, gdy przepływ ludności nie jest rejestrowany na granicy państwa, trudno właściwie ocenić faktyczny stan zarobkujących za granicą. Ocenia się, „że w 2007 roku poza granicami Polski przebywało czasowo około 2270000 mieszkańców naszego kraju. W 2008 roku liczba ta zmniejszyła się o 60000 i wynosiła 2210000 . W 2009 roku miał miejsce dalszy spadek liczby wyjazdów za granicę zarówno na pobyt stały, jak i czasowy w celach zarobkowych. Jednocześnie obserwowano wzrost liczby powrotów z zagranicy, co miało prawdopodobnie związek ze światowym kryzysem i pojawieniem się trudności na rynkach pracy za granicą. Powroty nie miały jednak masowego charakteru. Decyzję o powrocie podejmowali Polacy, 
którzy przebywali za granicą na stałe. Badani wracali głównie z Irlandii, Wielkiej Brytanii, USA i Niemiec"12.

$\mathrm{Z}$ analizy wynika, że „wśród osób, które wyemigrowały w latach 2005-2009 większość stanowili mężczyźni (około 67,0\%). Relatywnie częściej były to osoby z wykształceniem średnim lub zasadniczym zawodowym. Największą grupą emigrującą zarobkowo byli mieszkańcy wsi, stanowili ok. 37,0\%”³. Natomiast według Narodowego Spisu Powszechnego, który odbył się w 2011 roku, szacuje się, że różnica migrujących, uwzględniając zmienną płeć, pozostaje relatywnie stała (zob. wykres 2). Ponadto „najczęściej migrują osoby w stanie małżeńskim - 45 proc.; dalej single - 34 proc., osoby rozwiedzione 7 proc., stanu wdowiego -2 proc."14.

Powyższe dane potwierdzają się w szacunkach Głównego Urzędu Statystycznego, z których wynika, iż w 2006 roku nastąpił gwałtowny wzrost liczby emigracji na pobyt stały, co może mieć związek z decyzją podjęcia migracji osiedleńczej, jak również z decyzją związaną z unikaniem płacenia podatków za zarobki osiągnięte z pracy za granicą. W ostatnich piętnastu latach odnotowywano rokrocznie 20-25 tys. emigrantów. W roku 2006 liczba emigrantów wyniosła prawie 47 tys. $Z$ kolei $\mathrm{z}$ danych opracowanych przez Ośrodek $\mathrm{Ba}$ dań nad Migracjami Uniwersytetu Warszawskiego wynika, że co jedenasty Polak w przedziale wiekowym 20-29 lat zdecydował się

12 D. Becker-Pestka, Rodzina w obliczu migracji zarobkowej, „Colloquium WNHiS” $2012 \mathrm{nr}$ 1, s. 12.

13 Raport „Diagnoza Społeczna 2009”, [w:] Warunki i jakośćżycia Polaków, red. J. Czapiński, T. Panek, Warszawa 2009, s. 25.

14 K. Slany, M. Ślusarczyk, Migracje zagraniczne Polaków w świetle NSP 2011. Trendy i charakterystyki socjo-demograficzne, Kraków 2013, s. 9, www.euroemigranci.pl (05.05.2014). 
na wyjazd w czasie po 1 maja 2004 roku $^{15}$. Skalę migracji w latach 2004-2011 prezentują wykres 2 oraz tabela.

Wykres 2: Skala migracji zarobkowej w latach 2002-2012 (dane w tys.)

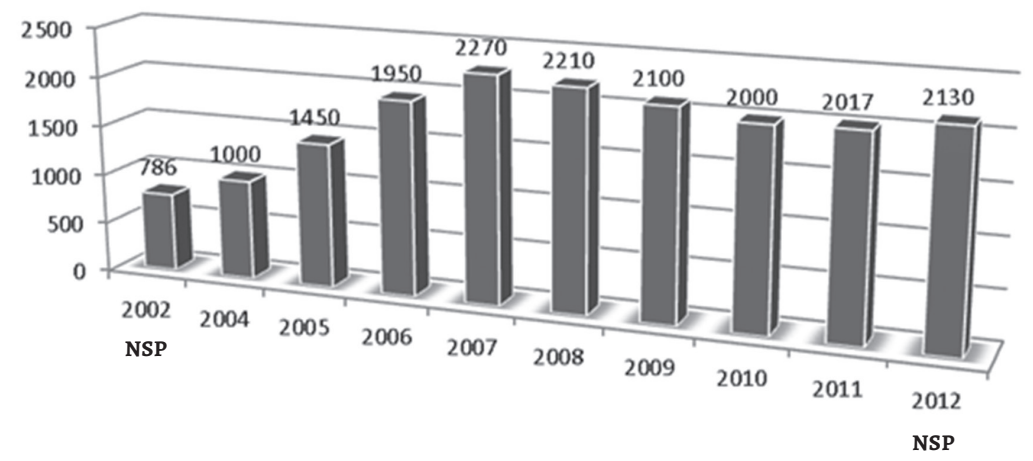

Źródło: Emigracja Polaków w latach 2004-2011, http://www.egospodarka.pl/ (05.05.2014).

Główny Urząd Statystyczny szacuje, że pod koniec 2012 roku za granicą przebywało czasowo około 2130 tys. mieszkańców Polski, tj. o 70 tys. więcej niż w 2011 roku (około 2060 tys.). W Europie W 2012 roku przebywało ponad 1816 tys. osób (w 2011 roku - około 1754 tys.), przy czym większość z nich (około 1720 tys.) emigrantów z Polski przebywała w krajach członkowskich Unii Europejskiej. Ta liczba zwiększyła się o 50 tys. W stosunku do 2011 roku. Spośród krajów UE najwięcej osób przebywało w Niemczech, Wielkiej Brytanii, Irlandii, Holandii oraz we Włoszech ${ }^{16}$.

15 K. Iglicka, Kontrasty migracyjne Polski, Warszawa 2008, s. 18-20.

16 Główny Urząd Statystyczny, Informacja o rozmiarach i kierunkach emigracji Polski w latach 2004-2012, Warszawa 2013, s. 1-2. 
Tabela 2: Skala migracji zarobkowej Polaków w latach 2004-1011

\begin{tabular}{|c|c|c|c|c|c|c|c|c|c|c|}
\hline \multirow{2}{*}{$\begin{array}{c}\text { Kraj } \\
\text { przebywania }\end{array}$} & \multicolumn{10}{|c|}{ Liczba emingrantów w tys. } \\
\hline & $\begin{array}{l}\text { NSP } \\
2002\end{array}$ & 2004 & 2005 & 2006 & 2007 & 2008 & 2009 & 2010 & $\begin{array}{l}\text { NSP } \\
2011\end{array}$ & 2011 \\
\hline OGÓŁeM & 786 & 1000 & 1450 & 1950 & 2270 & 2210 & 2100 & 2000 & 2017 & 2060 \\
\hline EUROPA & 461 & 770 & 1200 & 1610 & 1925 & 1887 & 1765 & 1685 & 1693 & 1754 \\
\hline \multicolumn{11}{|l|}{ w tym: } \\
\hline $\begin{array}{l}\text { UNIA EUROPEJSKA } \\
\text { (27 KRAJÓW) }\end{array}$ & 451 & 750 & 1170 & 1550 & 1860 & 1820 & 1690 & 1607 & 1622 & 1670 \\
\hline \multicolumn{11}{|l|}{ w tym: } \\
\hline Austria & 11 & 15 & 25 & 34 & 39 & 40 & 36 & 29 & 24 & 25 \\
\hline Belgia & 14 & 13 & 21 & 28 & 31 & 33 & 34 & 45 & 47 & 47 \\
\hline Cypr & - & - & - & - & 4 & 4 & 3 & 3 & 3 & 3 \\
\hline Dania & - & - & - & - & 17 & 19 & 20 & 19 & 18 & 21 \\
\hline Finlandia & 0,3 & 0,4 & 0,7 & 3 & 4 & 4 & 3 & 3 & 2 & 2 \\
\hline Francja & 21 & 30 & 44 & 49 & 55 & 56 & 60 & 60 & 62 & 62 \\
\hline Grecja & 10 & 13 & 17 & 20 & 20 & 20 & 16 & 16 & 17 & 15 \\
\hline Hiszpania & 14 & 26 & 37 & 44 & 80 & 83 & 84 & 48 & 45 & 40 \\
\hline Irlandia & 2 & 15 & 76 & 120 & 200 & 180 & 140 & 133 & 131 & 120 \\
\hline Niderlandy & 10 & 23 & 43 & 55 & 98 & 108 & 98 & 92 & 92 & 95 \\
\hline Niemcy & 294 & 385 & 430 & 450 & 490 & 490 & 465 & 440 & 437 & 470 \\
\hline Portugalia & 0,3 & 0,5 & 0,6 & 1 & 1 & 1 & 1 & 1 & 1 & 1 \\
\hline Republika Czeska & - & - & - & - & 8 & 10 & 9 & 7 & 7 & 7 \\
\hline Szwecja & 6 & 11 & 17 & 25 & 27 & 29 & 31 & 33 & 34 & 36 \\
\hline Wielka Brytania & 24 & 150 & 340 & 580 & 690 & 650 & 595 & 580 & 601 & 625 \\
\hline Włochy & 39 & 59 & 70 & 85 & 87 & 88 & 88 & 92 & 94 & 94 \\
\hline $\begin{array}{c}\text { KRAJE SPOZA } \\
\text { UNII EUROPEJSKIEJ }\end{array}$ & 10 & 20 & 30 & 60 & 65 & 67 & 75 & 78 & 71 & 85 \\
\hline w tym: Norwegia & - & - & - & - & 36 & 38 & 45 & 50 & 43 & 56 \\
\hline
\end{tabular}

Źródło: opracowanie własne na podstawie danych GUS 
W obecnym czasie najwięcej Polaków wyjeżdża do Niemiec i Wielkiej Brytanii. Szacuje się, że w roku 2012 do Niemiec na pobyt stały wyjechało prawie blisko 10 tys. Polaków, zaś do Wielkiej Brytanii prawie 5 tys. (por. wykresy 3 i 4). Natomiast $z$ informacji statystycznych i medialnych wynika, że w 2013 roku ogólnie w poszukiwaniu pracy wyjechało blisko 70 tys. Polaków. Ta konstatacja pozwala przyjąć wniosek, że exodus migracyjny trwa.

Wykres 3 i 4: Migracje zagraniczne Polaków do Wielkiej Brytani i Niemiec na pobyt stały w latach 2005-2012

WIELKA BRYTANIA

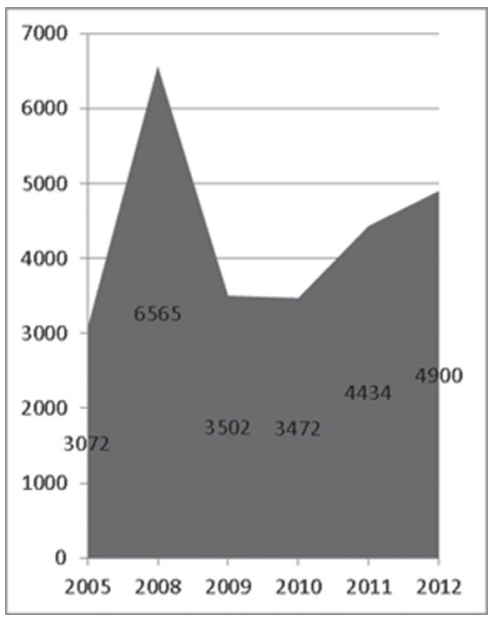

NIEMCY

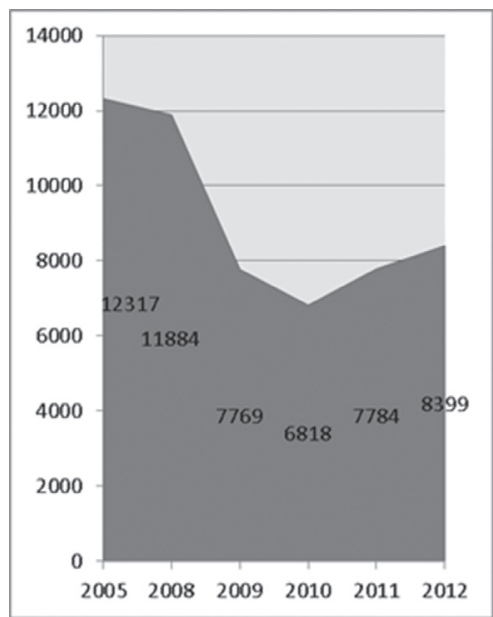

Źródło: „Rocznik Demograficzny” 2006, 2009, 2010, 2011, 2012, 2013.

Wydaje się zatem, że określenie skali migracji zarobkowych jest dość trudne. Trudno bowiem ustalić stan współczesnej mobilności Polaków, jak również kwestię mieszania się typów i kategorii migracji, tym bardziej iż obecnie migracje to coraz rzadziej jednorazowe 
przemieszczanie się związane ze zmianą stałego zamieszkania, a w większym stopniu krótkotrwałe formy mobilności, często raczej cyrkulacje niż „typowe” migracje ${ }^{17}$.

\subsection{Dylematy alternacji w rodzinie:}

\section{praca w kraju ojczystym czy w „drugiej ojczyźnie”}

Życie człowieka w przestrzeni społecznej to nieustanny proces podejmowania różnych decyzji. Jedne z nich są przyjemne, wartościowe, podnoszące jego status i prestiż, inne z kolei lokują się w przestrzeni jego porażki. Dlatego też hipotetycznie każdy z nas ulega zjawisku alternacji oznaczającej przyswajanie pewnych idei, decyzji nieraz nawet sprzecznych z systemem aksjonormatywnym. W nauce każda podejmowaną decyzję interpretuje się jako życiowo ważną, znacząca, doniosłą. Każda zatem alternacja jednostki musi zostać niejako aksjologicznie uprawomocniona, co umożliwia osobie poruszanie się i podejmowanie decyzji w kontekście jej uwarunkowań społecznych.

Dylemat zaś operacjonalizuje się jako konieczność wyboru czegoś albo kogoś. Nie jest to tylko wybór dla wyboru rzeczy, przedmiotu, zdarzenia. Jest to raczej koniecznościowe podejście do wyboru miedzy dwiema niewygodnymi, chociaż nieraz bardzo atrakcyjnymi możliwościami. Należy zatem odróżnić dylemat od problemu. Problemem jest jakaś trudna sytuacja, którą należy rozwiązać. Natomiast dylemat to intelektualne przemyślenie wszystkich podejmowanych decyzji w aksjomacie „za i przeciw”. Według Petera Lindsaya i Donalda Normana to stan psychiczny racjonalnej analizy

17 D. Kaczmarczyk, J. Tyrowicz, Wspótczesne migracje Polaków, Warszawa 2007, s. 5. 
pewnej decyzji (racji) za i przeciw oraz emocjonalnej rozterki w podejmowaniu decyzji ${ }^{18}$.

Nie ulega wątpliwości, że jedną z najtrudniejszych decyzji, jakie musi podjąć człowiek w przypadku niemożności znalezienia pracy na rynku własnego kraju, jest decyzja wyjazdu do pracy za granicą. Decyzja ta jest tym trudniejsza, im człowiek jest starszy, trudniej też, gdy ma małe dzieci. Wówczas myśli towarzyszące rodzinie i wyjeżdżającemu tworzą pewną wizję niepewności, niejako uprzedzająco lokują się w przestrzeni osobowości, zakotwiczają w psychice i prowadzą do wielu trudnych decyzji. Ale co zrobić, gdy warunki ekonomiczne (brak pracy, brak środków do życia) wpływają destabilizująco na poczucie godności i szacunku w rodzinie. Takie sytuacje zmuszają do wyjazdu.

Dylematy ludzkie podlegają procesom kategoryzacji według pewnych zmiennych. W przypadku osób podejmujących migrację zarobkową zmienne te należy określić jako kryterium czasu i treści. Jak zaznacza Władysław Szewczyk, zmienna czasu określa dylemat myśli i przeżyć. W tym kontekście należy zwrócić uwagę na myśli i przeżycia:

- „przed decyzją wyjazdu: jechać czy nie jechać, jakie mogą być przewidywane plusy i minusy, jakie zyski (np. materialne), a jakie straty (np. emocjonalne), jakie szanse, a jakie zagrożenia, czy sobie poradzę itp. Cała gama pytań, nawet rozterek. A to, czy i ile ich będzie, to zależy między innymi od cech osobowości, od odporności psychicznej, od dotychczasowych doświadczeń itp.;

18 P. Lindsay, D. Norman, Procesy przetwarzania informacji u człowieka, tłum. A. Kowaliszyn, Warszawa 1991, s. 428-550. 
- gdy już tam jestem - w czasie pobytu: jak się przystosować, jak poradzić sobie ze zderzeniem oczekiwań z rzeczywistością; jak pogodzić to, że jestem obcy, a pozostać sobą; jak przystosować się do całkowicie zmienionych warunków; jak nie ulec złym kuszeniem, jak zachować swoje zasady, swoją tożsamość, i to zarówno osobistą, jak też kulturową, religijną, narodową;

- kiedy z różnych powodów (sytuacja w rodzinie w Polsce: utrata pracy lub oczekiwanej płacy, stan zdrowia itp.) dochodzę do wniosku, że jednak muszę wracać;

- sytuacje po powrocie: jak wrócić do rytmu zajęć lub braku zajęcia $\mathrm{w}$ domu rodzinnym; albo gdy po powrocie znajduje migrant rodzinę "zmienioną", choćby w wymiarze usamodzielnienia się współmałżonka, dzieci (np. słowa żony «bez ciebie musiałam sobie radzić - nie jesteś mi potrzebny»); jak zagospodarować zarobek albo jak przetrawić porażkę, że nie udało się - nie warto było, «za dużo straciłem, ponieważ synek mnie nie poznaje», albo dorastający oświadcza - nie mam ci nic do powiedzenia"19.

Osoba podejmująca decyzje wyjazdu musi zmierzyć się również ze zmienną „treścią”, czyli określeniem tego zjawiska w kontekście uwarunkowań psychicznych. Wówczas dylematy migranta można racjonalizować w sferze myśli oraz uczuć i emocji:

- w sferze uczuć - człowiek, który z natury jest bardzo refleksyjny, będzie analizował ten dylemat bardzo drobiazgowo, niejako dokonując jego deskrypcji i roztrząsając na kilkanaście elementów;

- w sferze uczuć i emocji - jednostka będzie przeżywać i martwić się o swojego współmałżonka oraz dzieci (czy sobie poradzą); będzie

19 W. Szewczyk, Sekrety mocnych rodzin a dylematy rozłąki migracyjnej, [w:] Rodzina a migracja, dz. cyt., s. 45-46. 
się zastanawiać, czy wyjeżdżając, nie doświadczy porażki w swoim życiu; kto zaopiekuje się starszymi rodzicami ${ }^{20}$.

Dylematy migranta można również analizować w kontekście religijnym własnego sumienia, zastanawiając się nad tym, co ważniejsze: pieniądze czy rodzina.

W rzeczy samej podjęcie decyzji o wyjeździe „za chlebem”, nie jest łatwe. Pojawiają się nie tylko liczne pytania, na które próbuje odpowiedzieć rodzina, ale też sam zainteresowany migracją zastanawia się nad tym, jak ułożyć swoje życie. Czy szukać pracy z dala od rodziny? A może czekać na zmianę rynku pracy i przez jakiś czas żyć jedynie na zasiłku dla bezrobotnych? Jeśli wyjadę, jak poradzę sobie bez języka, znajomości, mieszkania? Trzeba jednak spróbować, przecież tylu Polaków już wyjechało i żyje im się lepiej. Tego typu dylematy coraz częściej dotykają rodzin w polskim społeczeństwie.

Istotnie ważnym elementem dylematu migracji w rodzinie jest zderzenie się z rzeczywistością światopoglądową, kulturową, społeczną w „drugiej ojczyźnie”. Zygmunt Bauman stwierdza: „bezpieczeństwo to tyle, co pewność; a znów: pewnym można się czuć tam, gdzie nie spodziewamy się niczego zaskakującego, nie musimy się obawiać czegoś całkiem i zupełnie obcego - czyli całkiem i zupełnie niezrozumiałego; a więc, jakby powiedział Wittgenstein, czegoś, co nie zawiera nie tylko instrukcji, ale choćby aluzji do tego, jak się wobec niego zachować. Stratę ojczyzny uświadomił sobie wtedy, gdy ocknął się w otoczeniu znaków, które były dlań «równie nieczytelne jak etruskie pismo»: «Twarze, gesty, stroje, domy,

20 W. Szewczyk, Sekrety mocnych rodzin a dylematy rozłąi migracyjnej, dz. cyt., s. 46. 
słowa», pozostając doznaniami zmysłów, przestały być znakami. Jeśli ojczyzna jest siedzibą ładu, przewidywalności i pewności siebie, obczyzna jest domeną nieładu, zaskoczenia i konfuzji. Jeśli się dość długo na obczyźnie przebywało, można się nauczyć wynajdywania czy choćby domyślania ładu znaczeń w chaosie doznań; ale „dla emigranta, który znalazł się w obcym kraju już jako osoba dorosła, takie rozeznanie $w$ znakach nie będzie odruchowe, a będzie stanowiło raczej akt intelektualny, związany z pewnym umysłowym wysiłkiem"21.

Oczywiste i naturalne wydaje się, że osoba, która znajdzie się $\mathrm{w}$ innym kraju, na początku przeżywa szok kulturowy, uwarunkowany odmiennością świata, tradycji, obyczajów, systemu normatywnego. U jednych ten „inny świat” budzi poczucie zachwytu, dla drugich jest środowiskiem zagubienia, jakiegoś zamętu natury egzystencjalnej. Wówczas niektórzy zastanawiają się nad trafnością właściwego wyboru, rozmyślają i analizują własne cele i motywacje. Uświadamiają sobie, że zostali zmuszeni nie tylko do wyjazdu, ale też do prowadzenia podwójnego życia - w kraju i na obczyźnie.

Stabilizując swoje życie w kraju zarobkowania, doświadczają kolejnego dylematu związanego z wyborem, czy kultywować i bronić własnych obyczajów, czy próbować wtopić się w otoczenie, dokonując asymilacji i akomodacji kulturowej ${ }^{22}$. Powszechnie jednak

21 Z. Bauman, Nieludzkość jest w ludzkiej mocy, „Gazeta Wyborcza” 2009 nr 5, s. 8.

22 Świadectwo: „W Niemczech pracuję już od czterech lat. Początkowo było trudno, nie mogłem się przyzwyczaić do ich tradycji, różnych sytuacji. Do tego nie znałem jeszcze języka. Teraz, kiedy nauczyłem się biegle mówić po niemiecku, wszystko się zmieniło; przyzwyczaiłem się. Mam dobrą pracę; poznałem bardzo fajną dziewczynę. Do Polski już 
wiadomo, że emigranci nie są przyjmowani przez obcych z otwartymi rękami. Najczęściej zjawisku temu towarzyszy ostrożność obu stron. I jeśli zetknięciu się z nową kulturą nie towarzyszy etnocentryzm (uznawanie własnej kultury za jedynie możliwą), wówczas asymilacja jest łatwiejsza. Przyjeżdżający niejako w pewnej części rezygnują z własnej obyczajowości, przyjmując wzorce dominującej kultury, zaś przyjmujący otwierają się na cenne imperatywy przywiezionej kultury, regionalizmu, folkloru.

W tym zakresie polityki emigracyjnej Dariusz Niedźwiedzki zauważył, że „model zróżnicowania kulturowego polega na włączaniu członków mniejszości etnicznych do grupy większościowej z możliwością zachowania ich odmienności kulturowej. Taka polityka pozwala wykorzystać potencjał mniejszości etnicznych w szerszym otoczeniu. Jednocześnie sprzyja podtrzymywaniu i rozwojowi tożsamości etnicznych zarówno grupy dominującej, jak i grup mniejszościowych. Stosowany w tym modelu proces nauki tolerancji dla odmienności umożliwia nie tylko poznanie obcych kultur, ale także uświadomienie sobie specyfiki własnej etniczności, jej rewitalizację w kontakcie $z$ innymi. Model ten w praktyce przyjmuje dwie odmienne formy. Pierwsza polega na pozostawieniu mniejszości samych sobie. Mogą one kultywować i rozwijać własną kulturę, pod warunkiem że je na to stać materialnie. Drugi polega na organizacyjnym

nie wrócę. Trochę mnie dziwią jeszcze niektóre zachowania Niemców, ale poza tym wszystko jest ok. Największym jednak problemem było dla mnie niezachowywanie postu w piątek. U nas w Polsce odmawiamy sobie w tym dniu pokarmów mięsnych, a tutaj prawie tego nie ma i nikt nie przestrzega postu w piątek. Musiałem się więc do nich upodobnić" (Władek, lat 35). J. Młyński, W. Szewczyk, Rodzina wobec dylematów migracji zarobkowej, Warszawa 2012, s. 84. 
i finansowym udziale instytucji państwa w podtrzymywaniu odmienności kulturowej grup mniejszościowych"²3.

Niezależnie od procesu kulturowego rozterki migrujących za granicę pojawiają się przede wszystkim w sytuacji, gdy podjęcie decyzji jest wielką niewiadomą, bo opartą głównie na doświadczeniach innych osób - bliższych lub dalszych. Ponadto informacje medialne mogą być źródłem tematów do przemyśleń. Wreszcie dylematy przeżywa emigrant już po wyjeździe z kraju, po opuszczeniu rodziny. Pojawiają się pytania, jak przeżyć w nowych warunkach, aby pozostać sobą. Są to zagadnienia egzystencjalne, ale i moralne. $\mathrm{Z}$ kolei decyzja o powrocie z migracji, również wytwarza nie tylko nową sytuację ekonomiczna, ale też i niepewność odnalezienia się na nowo w rodzinie.

"Druga ojczyzna”, jak się wydaje, dla osób decydujących się na migrację zarobkową jest bardzo trudnym wyzwaniem. $Z$ jednej strony każdy człowiek chciałby kształtować i rozwijać swoje życie w ojczystym kraju. W nim zakładać rodzinę i w nim pielęgnować aksjologiczne piękno własnej egzystencji, zaspokajając pierwszoi drugorzędne potrzeby. $Z$ drugiej strony brak pracy, niska płaca, wysoka stopa bezrobocia, wymagający rynek pracy zmuszają jednostkę do opuszczenia własnej ojczyzny - jeśli nie na pobyt stały, to przynajmniej czasowy. Podjęcie takiej decyzji nie jest łatwe. $Z$ kolei praca w ojczyźnie, dramatycznie nisko płatna, nie pozwala właściwie funkcjonować. Powszechnie bowiem wiadomo, że współczesne rodziny są pokoleniem tysiąca. Wynagrodzenie za pracę w ekonomicznym rachunku matematycznym mieszczącym się w przedziale tysiąca

23 D. Niedźwiedzki, Migracje i tożsamość. Od teorii do analizy przypadku, Kraków 2010, s. 92-93. 
złotych nie pozwala rodzinie zaspokoić nawet tych pierwszych najbardziej podstawowych potrzeb.

Niewątpliwie migrant, zanim podejmie decyzję, przeżywa emocjonalne rozterki, analizuje argumenty, które pchają go do wyjazdu, jak i te, które - jak sądzi - mogą być zagrożeniem. Realistyczna ocena szansy powodzenia musi zakładać też ryzyko porażki. Nic zatem dziwnego, że człowiek prowadzi sam ze sobą dialog, który w komunikacji określamy jako decyzję. Z jednej strony nie utracić piękna i szczęścia rodziny, z drugiej żyć na poziomie godności i względnego rachunku ekonomicznego.

\section{Blaski migracji zarobkowej dla rodziny}

Wśród badaczy zjawiska migracji zarobkowej istnieje zgodność, iż każda migracja przynosi wiele korzyści. Jest również pewnego rodzaju „startem” w życie dla rodziny doświadczającej tego zjawiska, tym bardziej że jedną z ważnych kwestii decydujących o jakości życia rodziny jest jej poziom ekonomiczny. Zarówno posiadanie odpowiednich zasobów ekonomicznych, zaspokajanie wielu potrzeb, jak też uczestnictwo $\mathrm{w}$ życiu towarzyskim, kulturalnym, realizacja życiowych planów i aspiracji edukacyjno-wychowawczych niewątpliwie pozytywnie wpływają na rodzinę. Trzeba sobie uświadomić, że wiele polskich rodzin nie tylko doświadcza ubóstwa, ale permanentnie zmaga się z brakiem wystarczających środków do zaspokajania najważniejszych potrzeb egzystencji. W tym kontekście migracja zarobkowa jest pewnym sposobem na rozwiązanie trudności ekonomicznych ${ }^{24}$.

24 D. Becker-Pestka, Rodzina w obliczu migracji zarobkowej, dz. cyt., s. 10. 
Pewna część autorów podejmujących badania na temat migracji zarobkowych rodziców pomimo społecznego sprzeciwu wobec tego zjawiska zauważa w tym procesie wiele pozytywnych skutków. W ten sposób wskazują nie tylko na czynniki ekonomiczne, ale również na możliwość realizacji planów życiowych jednostki, pozytywną zmianę rodziny jako grupy społecznej. Dlatego też, chociaż „migracja postrzegana jest jako swego rodzaju „zło konieczne”, nie można zaprzeczyć, iż może ona przynosić korzyści”25.

Z przeglądu literatury wynika, że pomimo trudnych decyzji, jakie podejmują migranci, zjawisko to ma wiele pozytywnych aspektów. Najczęściej zalicza się do nich:

- „poprawę sytuacji materialnej rodziny skutkującą podniesieniem standardu zaspokajania potrzeb jej członków, finansowym wzmocnieniem procesu edukacji i startu życiowego dzieci;

- zwiększenie samodzielności współmałżonków, będące konsekwencją wykonywania czynności i podejmowania ról społecznych dotychczas realizowanych przez partnera;

- udział dzieci w prowadzeniu gospodarstwa domowego, stanowiący przygotowanie do pełnienia ról $\mathrm{w}$ dorosłym życiu;

- gromadzenie przez dzieci doświadczeń życiowych, wynikających z obserwacji sposobów rozwiązywania przez rodziców trudności, związanych z migracyjnym rozłączeniem rodziny;

- uświadomienie sobie w trakcie rozłąki uczuć łączących członków, a także znaczenia dla nich rodziny jako wspólnoty;

25 D. Gizicka, J. Gorbaniuk, M. Szyszka, Rodzina w sytuacji rozłąi migracyjnej, Lublin 2010, s. 89. 
- uzyskanie poczucia bezpieczeństwa w efekcie wyjazdu na emigrację członków zakłócających życie rodzinne (przemoc, patologiczne zachowania związane $z$ chorobą alkoholową itp.)".

Badacze procesu mobilności człowieka w zakresie migracji zarobkowych wskazują na kilka jej blasków: praca, dobra płaca, poprawa sytuacji ekonomicznej w rodzinie, lepszy start dla dzieci, relatywnie szybkie wybudowanie domu, kwalifikacje językowe, poznanie kultury - wielokulturowość, zdobycie kwalifikacji zawodowych, wartość świadectwa wobec wiary, możliwość założenia firmy w sytuacji remigracji, umocnienie miłości do własnej ojczyzny - patriotyzm, umocnienie więzi małżeńskiej (zob. schemat 1).

Pierwszym walorem migracji zarobkowej jest z d o by c i e p ra cy. Człowiek bowiem do zaspokojenia rozmaitych potrzeb koniecznie musi pracować. Praca jest zatem „nieodłącznie związana ze światem ludzkich potrzeb. Dzięki niej człowiek zdobywa bądź wytwarza dobra potrzebne mu do życia. Zaspokajanie potrzeb odbywa się przez przetwarzanie świata, który w ten sposób zostaje poddany człowiekowi. Ale najistotniejsze w fenomenie pracy jest nie tyle to, że jest ona przekształcaniem świata, ile to, że przez nią osoba ludzka urzeczywistnia samą siebie, że jest ona czynnikiem kształtowania jej własnego oblicza"26.

Praca $\mathrm{w}$ pewnym sensie pozostaje zarówno naturalną reakcją na potrzebę chleba, ale też reakcją na potrzebę własnego rozwoju, samorealizacji; daje poczucie szczęścia i satysfakcję z wykonanego zadania. Dlatego też lokuje się w przestrzeni ludzkiego bytowania jako podstawowa kategoria egzystencji. Samo znalezienie pracy

26 K. Krajeński, Etyka pracy, dz. cyt., s. 15. 
pozostaje wartością. Dzięki niej człowiek nie tylko wzmacnia się ekonomicznie, ale realizuje własne cele i ambicje. Wreszcie znalezienie pracy po długotrwałym bezrobociu jest aksjologicznie ważne, społecznie potrzebne, psychologicznie konieczne.

Praca $\mathrm{w}$ analizie socjologicznej określana jest jako ekonomiczna korzyść. Korzyści zaś mogą być zarówno indywidualne, jak i kolektywne. Zarobkowanie w innym kraju daje przede wszystkim korzyści osobiste, dzięki którym migrant może utrzymać siebie i rodzinę. Obserwator życia społecznego z łatwością zauważa, że wynagrodzenie uzyskiwane za pracę w krajach zachodniej Europy jest o wiele wyższe. Powszechnie przecież wiadomo, iż pracujący za granicą otrzymują pobory prawie czterokrotnie wyższe. Ponadto uzyskane pobory należałoby jeszcze zweryfikować z walutą, która realnie wzmacnia budżet jednostki. I chociaż koszty życia są na Zachodzie relatywnie wyższe, to jednak uzyskana zapłata wystarcza zarówno na godziwe życie, jak też na pewne oszczędności.

Kondycja finansowa jest równie ważnym aspektem i zarazem miernikiem życia społecznego. Dlatego też osoby podejmujące migrację zarobkową zwracają szczególną uwagę na uzyskane miesięczne wynagrodzenie. Dla rodziny to niezaprzeczalny warunek dalszego bytowania i podniesienia poziomu życia. Jest to również ważne, gdy rodzina zaciągnęła kredyt lub po prostu spłaca długi za bieżące wydatki. Nadto lepsza kondycja finansowa sprzyja integralnemu rozwojowi rodziny w różnych sektorach jej egzystencji, zwłaszcza gdy zachodzi potrzeba leczenia chorych członków rodziny. Tym samym atrakcyjne zarobki lokują się jako najważniejsze plusy migracji za granicę. Bez względnie właściwej ekonomii życie czasem traci sens, a rozdarta rodzina gubi się w społecznym funkcjonowaniu. 
Schemat 1: Blaski migracji zarobkowej

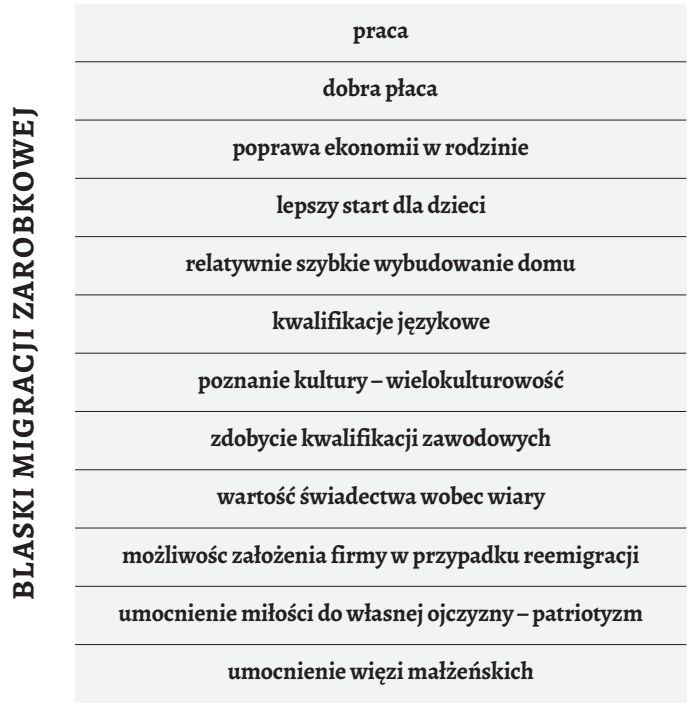

Źródło: opracowanie własne

Każda migracja daje wiele korzyści i lepszy start dla dzieci, które chcą podejmować studia, lepiej się ubierać, dostawać kieszonkowe. Edukacja jest współcześnie bardzo kosztowna - migracja pozwala podnieść status społeczny dzieci. Same zaś dzieci nie czują się źle w środowiskach swoich kolegów, bowiem nie doświadczają syndromu braku środków ekonomicznych. Wprawdzie ekonomia nie jest najważniejsza, ale relatywnie konieczna. $Z$ jej powodu często rodzą się konflikty między rodzicami a dziećmi, zwłaszcza wówczas, gdy dzieci nie potrafią zrozumieć trudnej sytuacji swoich rodziców.

Kolejnym pozytywnym aspektem dla rodzin podejmujących migrację zarobkową jest szansa na względnie szybkie wybudowanie domu lub zakup mieszkania. Uświadamiając sobie, z jakimi trudnościami borykają się dziś młodzi ludzie, zakładając swoje rodziny, 
szczególnie w przypadku zakupu mieszkania, uzyskanie większej gotówki jest dla nich niezwykle korzystne. Z kolei zakup mieszkania czy wybudowanie domu daje im poczucie samodzielności oraz szerszy zakres intymności. Równie istotnym plusem migracji jest poznanie nowego języka. Pracujące w obcym kraju osoby podejmują naukę $\mathrm{w}$ wieczorowych lub weekendowych szkołach językowych albo szlifują znajomość języka za pomocą konwersacji $\mathrm{z}$ native'ami.

Należy też zwrócić uwagę na kwestię poznania kultury w kraju pracy. „W trakcie migracji dochodzi do zjawiska dyfuzji kulturowej, która oznacza przestrzenne rozchodzenie się lub przenoszenie się elementów kultury (cech, instytucji, wzorów, wątków, tematów, obyczajów) w drodze zapożyczenia”27. Rzecz jasna, iż proces dyfuzji kulturowej dotyczy nie tylko kultury materialno-ekonomicznej, ale również kultury duchowej. I chociaż uzależniona jest ona od osobowości migranta, to jednak sieć interakcji sprawia, że każdy migrant uczestniczy w tym procesie. Zderzenie się z wielokulturowością związane jest $\mathrm{z}$ naśladownictwem społecznym danej osoby powielającej pewne zachowania i postawy tubylców. Wówczas przejęcie elementów kultury czy też jej recepcji pozwala migrantowi lepiej funkcjonować w kraju nowego osiedlenia. Oczywiście możemy się tu spotkać z tzw. synkretyzmem, który poprzez zderzenie się kultury migranta i tubylca prowadzi do wielu ciekawych konfiguracji kulturowych. Zjawiska te można określać jako pewien rodzaj hybrydyzacji obyczajowej, polegającej na połączeniu różnych elementów implikowanych „obcą kulturą” z jednej i drugiej strony.

27 D. Niedźwiedzki, Migracje i tożsamość..., dz. cyt., s. 115. 
Istotnym plusem migracji, jak się wydaje, jest zdobycie lub podniesienie kwalifikacji zawodowych. Chociaż - jak wynika z badań migranci w większości mają już zawód, to jednak w kraju własnego zamieszkania nie mogliby go rozwijać z powodu braku pracy zgodnej z kwalifikacjami. Natomiast w kraju migracji nie tylko pracują w wyuczonym zawodzie, ale również dzięki nowoczesnym technologiom rozwijają swoje umiejętności. Zdobycie większego doświadczenia pozwala im w sytuacji reemigracji założyć firmę w kraju ojczystym. Pobudza ich do tego nie tylko czynnik ekonomiczny, ale również kapitał ludzki zdobyty w kraju migracji. W ten sposób zdobyte doświadczenie i pozyskane pieniądze służą jako narzędzia przy rozwijaniu własnej przedsiębiorczości.

W analizie migracji zarobkowej Polaków warto zwrócić uwagę na wartość świadectwa wiary. To kolejna ważna zaleta mobilności człowieka. Wędrówka młodych ludzi, którym rodzice przekazali dziedzictwo wiary, przyniosła kościołowi (parafii) wiele duchowych korzyści. W tych bowiem krajach, gdzie katolicy stanowią mniejszość, młoda generacja Polaków o tradycyjnych wartościach i poglądach religijnych podnosi statystyki praktyk religijnych. Wprawdzie zostały utworzone ośrodki polonijne, które w jakiejś mierze moga świadczyć o zjawisku izolacji religijnej, jednak ludność tamtejszych krajów z podziwem patrzy na przeżywanie wiary i relacji do Boga przez Polaków. Wielu katolików nie wyobraża sobie życia w Europie bez Eucharystii i innych sakramentów. Młodzi ludzie organizują grupy przyparafialne, tworzą zespoły muzyczne, by w ten sposób służyć Bogu i ludziom. Ponadto wiele przypadków wskazuje, że emigracja dla wielu osób jest doświadczeniem autentycznego nawrócenia.

Wreszcie w kręgu blasków migracji zarobkowej znajduje się też poczucie piękna historii i dziejów własnego kraju. Budzi się tęsknota 
za ojczyzna, poczucie patriotyzmu, dziedzictwa kulturowego, kształtowanie tożsamości narodowej. Tożsamość to cecha albo zespół cech określających, „kim jest człowiek”. Szczególnie tożsamość społeczna, zwana też kolektywną, daje poczucie przynależności, do grupy, norm, zwyczajów, zasad, tradycji... Miłość do ojczyzny implikuje świadomość własnych korzeni, jest katalizatorem spójnych działań narodu. Daje odpowiedź na pytanie dotyczące wartości człowieka jako obywatela własnego kraju. Dopiero w zderzeniu z innym krajem (krajem zarobkowania) ojczyzna w świadomości migranta plasuje się na wysokim miejscu drabiny hierarchicznej. Pogląd ten podziela Dariusz Niedźwiedzki, stwierdzając, że „migranci przyjeżdżają do nowej rzeczywistości, posiadając określoną autoidentyfikację i sposoby identyfikowania innych. W odmiennych warunkach kulturowych okazują się one zazwyczaj nieadekwatne do oczekiwań i wymagań otoczenia społecznego"28.

Istotną zaletą migracji może być umocnienie więzi małżeńsko-rodzinnej. Jeśli w procesie migracji zarobkowej uczestniczą jednostki odpowiedzialne i emocjonalnie dojrzałe, wówczas rozłąka na jakiś czas może sprzyjać umocnieniu jedności wśród małżonków. Tęsknota za żoną lub mężem, dziećmi pozwala migrantowi uświadomić sobie wartość drugiej osoby, wartość rodziny, wspólnie spędzonych chwil. Stwierdzenie, iż dla prawidłowego funkcjonowania wspólnoty małżeńsko-rodzinnej konieczna jest bliskość fizyczna, psychiczna i emocjonalna ${ }^{29}$, w istocie rzeczy nie przeszkadza procesowi migrowania. W dużej mierze te trzy wymiary bytowania małżonków

28 D. Niedźwiedzki, Migracje i tożsamość..., dz. cyt., s. 145.

29 D. Gizicka, J. Gorbaniuk, M. Szyszka, Rodzina w sytuacji rozłąki migracyjnej, dz. cyt., s. 18. 
zależą od ich osobowości, ich poświęcenia, zrozumienia dylematu rozłąki. Istnieją również przypadki, gdy czasowa rozłąka wpłynęła na umocnienie wspólnoty małżeńsko-rodzinnej. Małżonkowie, którzy wcześniej często poddawali się zakłóceniom komunikacji międzyosobowej, w wyniku rozłąki i braku permanentnego dialogu uświadomili sobie potrzebę i wartość ich rodzinnego życia.

Rozstanie powoduje, że poszczególni członkowie rodziny zdają sobie sprawę, jakie uczucia ich łączą, co świadczy o ich roli jako jedności małżeńsko-rodzinnej. W rodzinach z problemem alkoholowym, przemocy lub autokratyzmu wyjazd przywraca poczucie bezpieczeństwa. Ponadto dzieci, które uczestniczą w czynny sposób w życiu domowym, przygotowują się do wypełniania w przyszłości różnych ról życiowych w swojej własnej rodzinie. Poprzez obserwację sposobów, w jaki osoby dorosłe radzą sobie z trudnościami, dzieci zdobywają różne umiejętności życiowe ${ }^{30}$.

\subsection{Konsekwencje migracji zarobkowej dla rodziny}

Powszechnie uznaje się, że migracja bardzo niekorzystnie zapisuje się w przestrzeni społecznej, ludzkiej oraz rodzinnej. Konsekwencje te można uznać za interdyscyplinarny koncept trudności w przestrzeni społecznej, dotyczą bowiem demograficznych, ekonomicznych, religijnych, społecznych, socjalnych, familiologicznych i teologicznych obszarów ludzkiego bytowania. Najważniejszym podmiotem konsekwencji migracji jest rodzina. W niej bowiem jak w kalejdoskopie odbijają się wszelkie niepokojące zmiany

30 D. Becker-Pestka, Rodzina w obliczu migracji zarobkowej, dz. cyt., s. 13. 
środowiska, w którym znajduje pierwotną egzystencję. Rodzina jest jak czuły sejsmograf, rejestrujący każdą nieobecność ojca lub matki, bez względu na czas trwania rozłąki.

Z literatury dotyczącej badań wyjazdów zagranicznych wynika, że „konkretne konsekwencje emigracji dla rodziny zależą od wielu czynników: czy cała rodzina emigruje, czy tylko któryś z jej członków, jak obce jest środowisko społeczne, kulturowe i religijne miejsca przeznaczenia; jakie czekają ją niedogodności w nowym środowisku... Nie bez znaczenia jest też odległość, która dzieli nowe miejsce pobytu od starego. Wprawdzie ten czynnik traci obecnie na znaczeniu z racji ułatwień przemieszczania się ludzi, ale nie zmienia to do końca faktu, że stanowi on pewną trudność w kontaktowaniu się, choćby z powodu kosztów podróży. W przypadku czasowej emigracji któregoś z członków rodziny ta okoliczność jest ogromnie ważnym czynnikiem"31.

Konsekwencją migracji jest przede wszystkim zagrożenie trwałości więzi pomiędzy małżonkami. Taka rozłąka może wprowadzić wiele zmian, niestety negatywnych. Wzrasta poczucie tęsknoty i osamotnienia, co powoduje poczucie utraty bezpieczeństwa. Na skutek tych negatywnych odczuć osoba szuka wsparcia i opieki w kimś innym. Takie zachowanie często prowadzi do zagubienia emocjonalnego, a w konsekwencji jest czynem zdrady, prowadzącym do formalnego lub nieformalnego rozpadu małżeństwa. Dla dzieci natomiast zagrożenie występuje w procesie właściwego wychowania. Utrata więzi społecznej i rodzinnej tworzy puste miejsce, a dziecko staje się produktem konsumpcyjnym. Nieobecność rodziców w życiu

31 W. Majkowski, Konsekwencje emigracji dla wspótczesnej rodziny polskiej, dz. cyt., s. 107. 
dziecka powoduje, że nie znają jego problemów ani jego samego. Dziecko czuje się osamotnione, pozbawione opieki. W takiej sytuacji problemy wychowawcze powodują trudności w funkcjonowaniu w rodzinie i w społeczeństwie ${ }^{32}$.

Badacze zajmujący się deskrypcją migracji są skłonni rozpatrywać i analizować konsekwencje tego zjawiska na dwóch poziomach: w stosunku do osoby migrującej oraz w stosunku do rodziny. W tym pierwszym zakresie można wskazać na następujące konsekwencje: praca o niskim prestiżu społecznym, traktowanie migranta jako osoby drugiej kategorii, trudna adaptacja migrującego w nowej rzeczywistości, związki kohabitacyjne oraz niewłaściwe zachowanie migranta. Natomiast w stosunku do rodziny: zanik więzi małżeńskiej, brak wierności - zdrada, rozpad małżeństwa - rozwody, uzależnienie, problemy wychowawcze z dziećmi, eurosieroctwo, moralne pęknięcia czy cierpienia seniorów (zob. schemat 2).

W stosunku do osoby migrującej należałoby zwrócić uwagę na konsekwencje, które wynikają z faktu znalezienia się w innym kraju oraz traktowania migranta w kraju zarobkowania. Należy sobie uświadomić, że w początkowej fazie migracji zarobkowej jednostka będzie zawsze wykonywała prace o niskim prestiżu. I chociaż żadna praca nie hańbi, bo nosi w sobie godność człowieka, to jednak z obserwacji wynika, że niektóre prace podejmowane przez migrantów w przestrzeni społecznej uznawane są za mało atrakcyjne dla tubylców. Ponadto wielu przedstawicieli krajów, do których migrują Polacy, traktuje przyjezdnych jako osoby drugiej kategorii. Tezę tę potwierdzają sami emigranci, którzy już od kilku lat

32 Encyklopedia pedagogiczna XXI wieku, red. T. Pilch, t. 5, Warszawa 2006, s. 334-335. 
żyją w „drugiej ojczyźnie”. Kolejną konsekwencją jest trudna adaptacja w nowej rzeczywistości. Wprawdzie każdy człowiek jest otwarty na wszelkie procesy kulturowe, ale ich asymilacja jest bardzo trudna.

Schemat 2: Konsekwencje migracji zarobkowej dla rodziny

\begin{tabular}{c} 
W STOSUNKU DO OSOBY MIGRU- \\
JĄCEJ \\
\hline praca o niskim prestużu \\
\hline $\begin{array}{c}\text { traktowanie migranta } \\
\text { jako osoby drugiej kategorii }\end{array}$ \\
\hline trudna adaptacja \\
w nowej rzeczywistości \\
\hline związki kohabitacyjne \\
\hline niewłasciwe zachowanie \\
migrującego
\end{tabular}

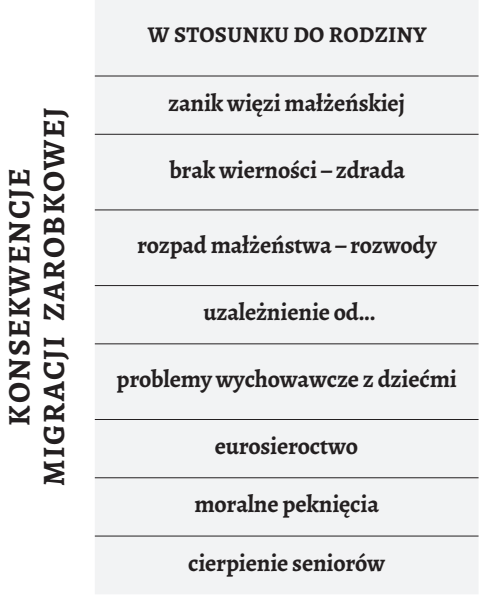

Źródło: opracowanie własne

Istotnie ważną konsekwencją jest fala związków kohabitacyjnych, szczególnie wśród młodej generacji. Jak się wydaje, moda jest jednym z ciekawszych zjawisk współczesności. Ulega jej zdecydowana większość członków każdego społeczeństwa. Jest to forma ulegania trendom czasów. W pewnym znaczeniu związki kohabitacyjne, szczególnie wśród najmłodszej generacji społeczeństwa, są formą mody. Migracja zaś sprzyja tego rodzaju modzie. Najczęściej dotyczy ona studentów lub osób tuż po zakończeniu studiów, którzy w poszukiwaniu pracy wyjeżdżają za granicę, zaś w realiach nowego społeczeństwa decydują się na wspólne zamieszkanie. Ponieważ już 
w kraju ojczystym łączyły ich bliskie relacje, na obczyźnie też żyją na prawach małżeńskich. Ten rodzaj kohabitacji z punktu socjologicznego można by nawet usprawiedliwić, o ile ów związek nie trwa długo. Jest to bowiem czas na lepsze poznanie się partnerów. Tym bardziej że - jak wskazują badania Doroty Gizickiej - prawie 80 proc. młodych ludzi żyjących w takich związkach pragnie zawrzeć formalny związek ${ }^{33}$.

W pewnym sensie konsekwencją migracji zarobkowej są niewłaściwe zachowania w kraju zarobkowania. Dotyczy to tych, którzy czas migracji, obok zdobywania środków ekonomicznych, traktują jako dobry sposób na wyluzowanie się; czas wolny od rodziny, od żony czy męża. Często uczestniczą w libacjach alkoholowych, a nawet emocjonalnie tracą międzyosobowy dystans, który skutkuje nowymi związkami, chwilowym zauroczeniem, zdradą. Tego typu zachowania są raczej domeną migracji sezonowej.

W rodzinie, która pozostaje w kraju ojczystym, konsekwencje migracji dotyczą szczególnie zerwania więzi małżeńskiej i rodzinnej. „Więź małżeńska w sytuacji rozłąki z przyczyn ekonomicznych jawi się jako pewnego rodzaju skutek ewolucji ekonomicznej funkcji rodziny, w której po wyjściu małżonków z pracy w przedsiębiorstwie domowym do zewnętrznych zakładów pracy, a zatem dość istotnym od siebie oddaleniu, małżonkowie nadal oddalają się od siebie przestrzennie i czasowo [...]. Takie rozciągnięcie odległości przestrzennej ich życia od siebie, jak również wydłużenie horyzontu czasowego przerw w ich spotkaniach, siłą rzeczy powiększa dzielący ich dystans psychiczny, nierzadko prowadząc do destrukcji małżeńskiej

33 Zob. D. Gizicka, Kohabitacja jako alternatywna forma życia rodzinnego, „Roczniki Nauk Społecznych” 2008 nr 1, s. 203. 
więzi" ${ }^{34}$. Następuje wówczas naruszenie podstawowego elementu spójności i jedności małżonków, jakimi są stale podtrzymywane interakcje i odniesienia między członkami rodziny. One bowiem utrwalają relacje i kształtują strukturę rodziny jako grupy społecznej35.

Ponadto zanik więzi małżeńskiej, a tym samym zanik komunikacji i utrzymujący się dystans między małżonkami oraz zdrada prowadzą do dramatycznej sytuacji w rodzinie, nader często kończącej się rozwodem. Rozwód zaś jest całkowitym zaprzestaniem wspólnoty życia małżeńskiego. Jego przyczyną mogą być również uzależnienia, w które czasem popadają migranci, szczególnie wówczas gdy nie radzą sobie z nową sytuacją w rzeczywistości nowego społeczeństwa.

W przypadku migracji rodziny istotny jest też problem właściwego wychowana dzieci. Badania dowodza, że wiele tego typu rodzin przejawia problemy wychowawcze. Brak ojca czy matki silnie wpływa na funkcjonowanie dzieci. Tym samym „pozostawienie dzieci pod opieką jednego z rodziców odciska często trwały ślad na psychice dziecka, jak np. lęk przed opuszczeniem, a także poczucie żalu, krzywdy, przygnębienie, smutek, skłonność do płaczu. Może się też pojawić poczucie winy"36. Dla małego dziecka istotny jest nie tylko sam fakt posiadania ojca i matki, ale też gesty, przytulenie, rozmowa, aktywny kontakt. Często brak rodziców owocuje problemami w szkole. Szczególnie starsze dzieci nawiązują podejrzane

34 K. Wojaczek, Więź małżeńska w sytuacji rozłąi z przyczyn ekonomicznych, Opole 2007, s. 211, za: D. Gizicka, J. Gorbaniuk, M. Szyszka, Rodzina w sytuacji rozłąi migracyjnej, dz. cyt., s. 19.

35 K. Szopińska, J. Szopiński, Satysfakcja z małżeństwa, „Novum” 6 (1980), s. 93.

36 J. Młyński, W. Szewczyk, Migracje zarobkowe Polaków, Tarnów 2010, s. 74. 
kontakty, dołączają do niewłaściwych grup, a nawet popadają w uzależnienia.

Kolejną konsekwencją migracji zarobkowej jest zjawisko eurosieroctwa ${ }^{37}$. Dzieci pozostawione dziadkom, sąsiadom doznają porzucenia przez swoich rodziców, czują się niekochane, niechciane, a w konsekwencji odrzucone. Tymczasem dzieci źle znoszą rozłąkę i choć mają rodziców, czują się sierotami. Stres i cierpienie okazują w różny sposób: gorzej się uczą, wagarują, popadają w uzależnienia. W skrajnych przypadkach są agresywne, wchodzą w konflikty z prawem.

W analizie konsekwencji dotyczących migracji warto zwrócić uwagę na moralne pęknięcia, które równie często destabilizują rodzinę. Dotyczą one nie tylko zaniku postaw religijności, niepraktykowania niedzielnej mszy świętej, ale również wewnątrzmałżeńskich i rodzinnych zachowań. Wreszcie ważnym następstwem migracji zarobkowej jest pozostawianie słabych i starszych rodziców w miejscu zamieszkania. Schorowani rodzice doznają wówczas nie tylko poczucia osamotnienia, ale często obwiniają się o brak właściwego wychowania swoich dzieci. Dzieci zaś doświadczają dylematu: co zrobić, kiedy z jednej strony należałoby otoczyć opieką rodziców, a z drugiej nie da się funkcjonować bez pracy.

37 „Przez pojęcie eurosieroctwa należy także rozumieć sytuację, w której emigracja zarobkowa rodziców/rodzica powoduje zaburzenie takich funkcji rodziny, jak: zapewnienie ciągłości procesu socjalizacji, wsparcia emocjonalnego dziecka i transmisji kulturowej. Zjawisko to stanowi bezpośrednią przyczynę występowania wielu problemów związanych z edukacją i wychowaniem dzieci i młodzieży pozostawionych bez należytej opieki”. W. Kądziołka, Problem eurosieroctwa a wychowanie w rodzinie, [w:] Rodzina a migracja, dz. cyt., s. 58. 


\section{Zakończenie}

Migracja jako proces mobilności człowieka w przestrzeni społecznej nie jest czymś nowym. Zmieniają się jedynie jej cechy i skala. W dyskursie społecznym odnosi się do funkcjonowania rodziny oraz państwa jako grupy społecznej. Ma zarówno pozytywne, jak i negatywne aspekty. Z bilansu wynika, że tych negatywnych jest o wiele więcej. $Z$ kolei decyzja wyjazdu uwarunkowana jest nie tylko kondycją ekonomiczną, ale przede wszystkim brakiem pracy na rynku ojczystego kraju.

Rzeczą jednak „najważniejszą jest, aby człowiek pracujący poza swym ojczystym krajem - to jako stały emigrant, czy w charakterze pracownika sezonowego, nie był w zakresie uprawnień upośledzany w stosunku do innych ludzi pracy w danym społeczeństwie. Emigracja za pracą nie może stawać się okazją do wyzysku finansowego lub społecznego. O stosunku do pracownika - imigranta muszą decydować te same kryteria, co w stosunku do każdego innego pracownika $\mathrm{w}$ tym społeczeństwie. Wartość pracy musi być mierzona tą samą miarą, a nie względem na odmienną narodowość, religię czy rasę. Tym bardziej nie może być wyzyskiwana sytuacja przymusowa, w której znajduje się emigrant" (LE 23).

W procesie migracji nie bez znaczenia pozostaje fakt, że transformacji ulegają również styl życia, zasady i wartości. Szczególnie gdy ostatecznym celem jednostki jest konsumpcjonizm oraz dominacja „mieć” nad „być”, tym bardziej że człowiek mający perspektywę lepszego życia, stabilniejszej pracy jakby nieco pogubił się w swoim wartościowaniu, zapominając o bliskich, a szczególnie dzieciach. Wydaje się bowiem, iż to właśnie dzieci płacą najwyższą cenę za każdy wybór swoich rodziców. Trzeba zatem uświadomić wszystkim 
podejmującym decyzję wyjazdu, że „hierarchia wartości, głęboki sens samej pracy domaga się, by kapitał służył pracy, a nie praca kapitałowi” (LE 23). W rzeczy samej należy pamiętać, iż migrację zarobkową poza ekonomicznym wymiarem cechuje również wymiar społeczny: rozbite małżeństwa czy osamotnione dzieci. Dlatego coraz częściej badacze tego zjawiska skłoni są twierdzić, że ceną za współczesną emigrację będzie nie tylko niż demograficzny czy starzejące się społeczeństwo. Ceną za emigrację może być kompletny upadek rodziny. 